\title{
Perubahan Mikrostruktur Jaringan Hati pada Mencit Model Sindrom Metabolik yang Diberi Fraksi Zingiber officinale
}

\author{
Dilla Latul Anjaniah, ${ }^{1}$ Eka Nurhayati, ${ }^{2}$ Herry Garna, ${ }^{3}$ \\ Annisa Rahmah Furqaani, ${ }^{4}$ Maya Tejasari, ${ }^{5}$ \\ ${ }^{1}$ Program Studi Pendidikan Dokter Fakultas Kedokteran Universitas Islam Bandung, \\ ${ }^{2}$ Bagian Ilmu Kesehatan Masyarakat Fakultas Kedokteran Universitas Islam Bandung, \\ ${ }^{3}$ Fakultas Kedokteran, Universitas Islam Bandung, \\ ${ }^{4}$ Bagian Histologi Fakultas Kedokteran Universitas Islam Bandung, \\ ${ }^{5}$ Bagian Biologi Medik Fakultas Kedokteran Universitas Islam Bandung
}

\begin{abstract}
Abstrak
Non-alcoholic fatty liver disease (NAFLD) merupakan penyakit perlemakan pada hati yang terjadi pada penderita sindrom metabolik. Penderita sindrom metabolik terjadi peningkatan kadar stres oksidatif sehingga muncul sel steatosis dan pelebaran sinusoid hati. Senyawa flavonoid dalam Zingiber officinale (jahe gajah) diketahui memiliki efek hepatoprotektif dan antiinflamasi dengan cara menghambat pembentukan reactive oxygen species (ROS). Tujuan penelitian ini mengetahui pengaruh fraksi etil asetat jahe gajah terhadap mikrostruktur jaringan hati pada mencit model sindrom metabolik. Objek penelitian ini menggunakan mencit jantan galur Swiss Webster yang berusia 36-40 minggu dibagi menjadi 4 kelompok. Penelitian dilakukan di Laboratorium Farmasi Institut Teknologi Bandung. Kelompok kontrol yang diberi pakan tinggi lemak tanpa diberikan terapi selama 28 hari. Kelompok IIIV diberi pakan tinggi lemak dan diterapi dengan diberi fraksi etil asetat jahe gajah dengan konsentrasi o,78 mg, 1,56 mg, dan 3,12 mg per kilogram bobot per hari diberikan secara oral. Observasi dan kuantifikasi mikrostruktur jaringan hati dilakukan menggunakan mikroskop cahaya. Hasil statistik jumlah sel steatosis belum menunjukkan hasil yang signifikan ( $\mathrm{p}>0,05)$, sedangkan pada jumlah pelebaran sinusoid menunjukkan hasil yang signifikan $(\mathrm{p}<0,05)$. Kekuatan korelasi konsentrasi fraksi jahe gajah dengan jumlah sel steatosis rendah, tetapi pasti $(r=-$ $0,381)$ dan pelebaran sinusoid cukup berarti $(\mathrm{r}=-0,451)$. Simpulan penelitian ini adalah pemberian fraksi etil asetat jahe gajah memengaruhi mikrostruktur jaringan hati pada mencit model sindrom metabolik.
\end{abstract}

Kata kunci: Hati, jahe gajah, NAFLD, sindrom metabolik, sinusoid, steatosis

\section{Liver Tissue Morphological Changes by Zingiber officinale Fractions in Metabolic Syndrome Mice Models}

\begin{abstract}
Non-alcoholic fatty liver disease (NAFLD) is a fatty liver disease that occurs in patients with metabolic syndrome. Patients with metabolic syndrome occur closer to oxidative stress that occurs in steatosis and dilation of the liver sinusoid. Flavonoid compounds in Zingiber officinale have hepatoprotective and anti inflammatory effects by inhibiting the formation of reactive oxygen species (ROS). The purpose of this study was to determine the content of Zingiber officinale ethyl acetate fraction on liver tissue microstructure in mice model of metabolic syndrome. This research method using mice of Swiss webster strain which had 36-40 weeks, divided into 4 groups. The study conducted at Pharmacology Laboratory Institut Teknologi Bandung. Control group fed high fat without therapy for 28 days. Group II-IV were fed high fat and treated with ginger elephant ethyl acetate fraction with a concentration of $0.78 \mathrm{mg}, 1.56 \mathrm{mg}$ and $3.12 \mathrm{mg}$ per kilograms of body weight per day, given orally. Observation and quantification of liver tissue microstructure was performed using a light microscope. The statistical results on steatosis cell counts did not show significant results ( $\mathrm{p}>0.05$ ), whereas the number of sinusoid enlargement showed significant results $(\mathrm{p}<0.05)$. Alternative strength of the Zingiber officinale fraction with a low but definite steatosis cell number $(\mathrm{r}=-$ $0.381)$ and significant sinusoid widening $(\mathrm{r}=-0.451)$. In conclusion, that administration of ginger elephant ethyl acetate fraction affected microstructure of liver tissue in mice model of metabolic syndrome.
\end{abstract}

Key words: Liver, metabolic syndrome, NAFLD, sinusoid, steatosis, zingiber officinale

Korespondensi: Dilla latul Anjaniah. Prodi Pendidikan Sarjana Kedokteran Fakultas Kedokteran, Universitas Islam Bandung. Jl. Tamansari no. 22, 40116, Kota Bandung, Provinsi Jawa Barat. HP: 082240664959, E-mail: dillaanjani24@gmail.com 


\section{Pendahuluan}

Non-alcoholic fatty liver disease (NAFLD) merupakan penyakit perlemakan hati yang terjadi pada penderita sindrom metabolik. ${ }^{1}$ NAFLD merupakan kumpulan gangguan hati yang ditandai dengan perlemakan hati makrovesikular, fibrosis, sirosis, dan tanpa hubungan dengan konsumsi alkohol. Telah diperkirakan bahwa komponen pada sindrom metabolik tersebut terlibat dalam patogenesis teori "two-hit". "Hit" yang pertama terjadi steatosis hepatic, terjadi ketidakseimbangan antara pembentukan dan perombakan trigliserida sehingga meningkatkan sintesis dan juga transpor trigliserida menuju hati. Lipogenesis dan sintesis trigliserida berlebihan pada akhirnya menyebabkan steatosis hepatik. Peningkatan kadar stres oksidatif dan inflamasi yang terjadi pada sindrom metabolik akan mendasari "Hit" yang kedua. Kadar reactive oxygen species (ROS) dan lipid peroxidase yang meningkat mengaktifkan sel-sel stelata menyebabkan steatohepatitis dan fibrogenesis yang akhirnya dapat terjadi perkembangan selanjutnya dari NAFLD menuju non alcoholic steato hepatitis (NASH) dan sirosis. ${ }^{2,3}$

Pengamatan degenerasi lemak secara histologi menunjukkan bahwa sel hepatosit yang mengandung banyak lemak terlihat sebagai vesikel kosong yang berbentuk bulat. ${ }^{4}$ Selain itu, gambaran histologi pada hati yang mengalami hiperlipidemia terdapat sel yang mengalami perlemakan (sel steatosis) dan sel nekrosis. Di samping itu, ditemukan sinusoid yang tampak melebar dan degenerasi lemak pada sel yang dilihat dari inti sel yang terdorong ke pinggir serta sel yang mengalami nekrosis. ${ }^{5}$ Dengan peningkatan kejadian NAFLD ini maka angka mortalitas menjadi tinggi sehingga diperlukan upaya kuratif yang aman dan murah untuk meningkatkan angka kesembuhan penderita.

Pengobatan yang saat ini masih digunakan sebagai antihiperlipidemia, yaitu menggunakan statin. Di sisi lain, Indonesia kaya akan bahan-bahan obat herbal yang mempunyai efek menurunkan kadar lemak dalam darah seperti senyawa flavonoid yang terkandung dalam Zingiber officinale (jahe gajah). Senyawa flavonoid dalam jahe gajah itu diketahui mempunyai efek antioksidan (efek hepatoprotektif) dan antiinflamasi dengan cara menghambat xanthine oxidase yang bertanggung jawab dalam pembentukan ROS. Penghambatan ROS ini dapat mengurangi cedera sel hati yang ditandai dengan sinusoid yang melebar, nekrosis, dan steatosis pada penderita NAFLD. ${ }^{6,7}$

Dalam penelitian ini dilaksanakan uji pemberian fraksi etil asetat jahe gajah untuk mengetahui efeknya terhadap kerusakan jaringan hati pada mencit model sindrom metabolik. Parameter yang diukur adalah jumlah sel steatosis dan pelebaran sinusoid serta ada tidaknya area nekrosis untuk menilai efek fraksi jahe gajah pada kerusakan jaringan hati akibat perlemakan hati. Hipotesisnya adalah bahwa fraksi jahe gajah memengaruhi mikrostruktur jaringan hati pada mencit tua model sindrom metabolik.

\section{Metode}

Subjek penelitian yang digunakan adalah 20 mencit (Mus musculus) jantan galur Swiss Webster yang berusia 36-40 minggu dengan bobot di atas 40 gram. Seluruh proses adaptasi maupun pemeliharaan dilaksanakan di Laboratorium Farmasi lantai 4 ITB. Tikus diadaptasikan dengan lingkungan laboratorium selama tujuh hari, kemudian tikus dibagi menjadi 4 kelompok perlakuan.

Kelompok I sebagai kontrol yang diberi pakan tinggi lemak ( $5 \mathrm{~kg}$ charoen pokphand (CP) 551 ditambah 1 $\mathrm{kg}$ lemak sapi larut dan 20 butir telur bebek) tanpa diberikan terapi selama 28 hari. Kelompok II-IV diberi pakan tinggi lemak dan diterapi dengan diberi fraksi etil asetat jahe gajah dengan konsentrasi o,78 mg, 1,56 $\mathrm{mg}$, dan 3,12 mg per kilogram bobot per hari diberikan secara oral selama 28 hari. Sampel didapatkan dari hati tikus postmortem dan pemeriksaan mikrostruktur jaringan hati dilaksanakan menggunakan mikroskop cahaya untuk menghitung jumlah sel steatosis dan melihat pelebaran sinusoid.

Konsentrasi dihitung berdasar atas konsentrasi crude ekstrak air jahe gajah sebesar $8.000 \mathrm{mg} /$ $\mathrm{kgBB} /$ hari, $16.000 \mathrm{mg} / \mathrm{kgBB} /$ hari, dan $32.000 \mathrm{mg} /$ $\mathrm{kgBB} /$ hari untuk manusia yang didapatkan dari penelitian sebelumnya. ${ }^{8}$ Kemudian, dikonversikan ke dalam bentuk dosis mencit menurut tabel konversi Paget dan Barnes. Kelompok II adalah $8.000 \mathrm{mg} \mathrm{x}$ $0,0026=20,8 \mathrm{mg} / \mathrm{kgBB} /$ hari, kelompok III 16.000 $\mathrm{mg} \times 0,0026=41,6 \mathrm{mg} / \mathrm{kgBB} /$ hari dan kelompok IV $32.000 \mathrm{mg} \times 0,0026=83,2 \mathrm{mg} / \mathrm{kgBB} / \mathrm{hari}$. Selanjutnya, dikonversikan ke dalam penghitungan konsentrasi fraksi etil asetat jahe gajah sesuai dengan jumlah volume yang didapatkan, yaitu etil asetat $=\mathrm{x}$ $100 \%=3,79 \%=0,0379$. Jadi, konsentrasi akhir hasil konversi etil asetat untuk mencit, yaitu kelompok II diberikan dosis 0,0379 x 20,8 mg = 0,78 mg/kgBB/ hari, kelompok III diberikan dosis 0,0379 x 41,6 mg = $1,56 \mathrm{mg} / \mathrm{kgBB} /$ hari, dan kelompok IV diberikan dosis $0,0379 \times 83,2 \mathrm{mg}=3,12 \mathrm{mg} / \mathrm{kgBB} /$ hari.

Pembuatan fraksi jahe gajah itu dilaksanakan di Laboratorium Central Unpad dengan optimasi prosedur tersendiri. Tahap pertama adalah pembuatan ekstrak air jahe gajah dengan menggunakan $26 \mathrm{~kg}$ jahe gajah yang sudah dicuci dan dipotong kecil. Selanjutnya, ekstrak dimasukkan ke dalam extractor beserta 100 liter air dengan suhu $60^{\circ} \mathrm{C}$ selama 6 jam. Diperoleh hasil ekstrak air jahe gajah sebanyak 100 liter dalam bentuk cair, kemudian masuk ke dalam tahap pemekatan dengan menggunakan concentrator suhu $45^{\circ} \mathrm{C}$ selama 5 jam. Didapatkan ekstrak air jahe gajah dalam betuk pekat sebanyak 2 liter. Selanjutnya, masuk ke dalam tahap pembuatan fraksi jahe gajah, yang pertama masukkan ekstrak air jahe gajah ke dalam corong pisah dan tambahkan pelarut $\mathrm{N}$ heksan (nonpolar) sebanyak 7,5 liter. Kemudian, kocok corong pisah sampai larutan dalam corong pisah memisah selama 3 hari fraksi N-heksan dipekatkan menggunakan evaporator dengan suhu $47^{\circ} \mathrm{C}$ sampai pelarut tidak dapat ditarik kembali. Hasil fraksi N-heksan jahe gajah yang didapatkan sebanyak 3,0021 gram atau $3 \mathrm{~mL}$ dalam bentuk pasta. Setelah itu, pembuatan fraksi dengan menggunakan 16 liter pelarut etil asetat (semi-polar) dengan prosedur yang sama. Kemudian, dipekatkan dengan evaporator suhu $47^{\circ} \mathrm{C}$ sampai pelarut tidak dapat ditarik kembali. Hasil fraksi etil asetat jahe gajah yang didapatkan sebanyak 19,0024 gram atau $23 \mathrm{~mL}$ dalam bentuk pasta. 
Pembuatan pakan tinggi lemak (PTL) dilakukan di Laboratorium Farmasi lantai empat ITB. Proses pembuatannya, yaitu $5 \mathrm{~kg}$ charoen pokphand (CP) 551 dihaluskan terlebih dahulu, kemudian ditambah 1 kg lemak yang sudah dipanaskan sampai larut dan dicampurkan dengan kuning telur bebek. Setelah itu diaduk-aduk hingga homogen serta dikeringkan menggunakan oven.

Pembuatan preparat dilakukan di Laboratorium Hewan dari Universitas Padjajaran. Langkah pertama hati mencit tersebut dibersihkan dengan menggunakan larutan normal saline; kemudian difiksasi di dalam formalin $10 \%$ selama 24 jam. Jaringan hati terlebih dahulu diproses memakai tissue processor sebelum kemudian ditanam di dalam parafin, lalu dipotong menggunakan mikrotom dengan ketebalan 4 sampai 5 $\mu \mathrm{m}$, lalu ditempelkan pada object glass dan dipanaskan dengan hot plate. Setelah itu, dilakukan deparafinisasi dengan xilol selama 6 menit, lalu secara berturut-turut dicuci dengan alkohol 90\%, 80\%, dan 70\%, kemudian object glass dicuci dengan air mengalir dan dilakukan pewarnaan dengan menggunakan hematoxylin dan eosin (H\&E).

Pemeriksaan preparat terlebih dahulu dibuat area-area lapang pandang dengan cara menggambar bangun persegi pada plastik mika yang kemudian ditempelkan di bawah preparat. Sampel diperiksa di bawah mikroskop cahaya dengan pembesaran 100 kali untuk melihat jaringan hati secara keseluruhan. Selanjutnya, untuk melihat jumlah sel steatosis dan jumlah pelebaran sinusoid dalam pembesaran 1.000 kali.

Rerata seluruh data disajikan secara deskriptif, kemudian analisis data dilaksanakan menggunakan

ANOVA (analisis varians) uji parametrik untuk melihat secara umum beda rerata jumlah steatosis dan pelebaran sinusoid jaringan hati mencit pada seluruh kelompok. Penelitian ini telah mendapatkan ethical clearance dari Komite Etik Penelitian Kesehatan Fakultas Kedokteran Universitas Islam Bandung Nomor 345/Komite Etik.FK/III/2018.

\section{Hasil}

Pengamatan gambaran umum mikrostruktur jaringan hati pada kelompok kontrol yang tidak diberi terapi menampilkan gambaran mikroskopis serupa dengan kelompok IV yang diberi terapi fraksi etil asetat jahe gajah dengan konsentrasi paling besar $(3,12 \mathrm{mg} / 20$ gBB/hari). Hasil observasi pada preparat jaringan hati dengan pembesaran 100x menunjukkan lempeng hepatosit hampir kehilangan susunan radiernya, vena sentral masih utuh, dan tidak ditemukan area nekrosis. Gambaran tersebut berbeda dengan gambaran jaringan hati pada kelompok II dan III yang pada pembesaran 100 kali menunjukkan gambaran lempeng hepatosit yang masih memiliki pola radier dengan vena sentral yang masih utuh serta tidak ditemukan area nekrosis (Gambar 1).

Pada pembesaran 1.00ox kelompok I dan IV sel steatosis tampak jelas dengan pelebaran sinusoid tidak terlalu nyata, tetapi pada kelompok II dan III steatosis dalam jumlah yang lebih sedikit dibanding dengan kelompok I dan IV dengan diameter sinusoid yang tampak melebar (Gambar 2).

Di bawah ini adalah hasil rerata jumlah sel steatosis

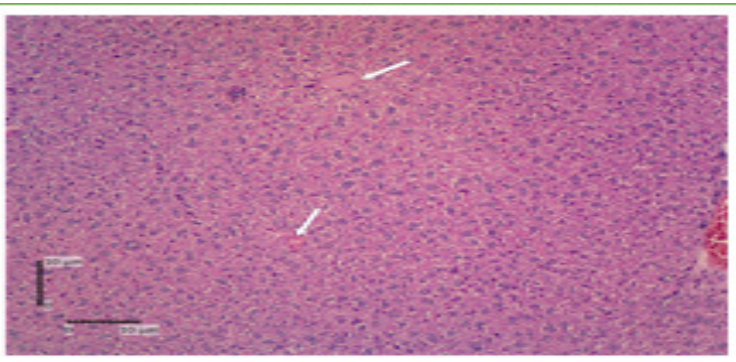

B
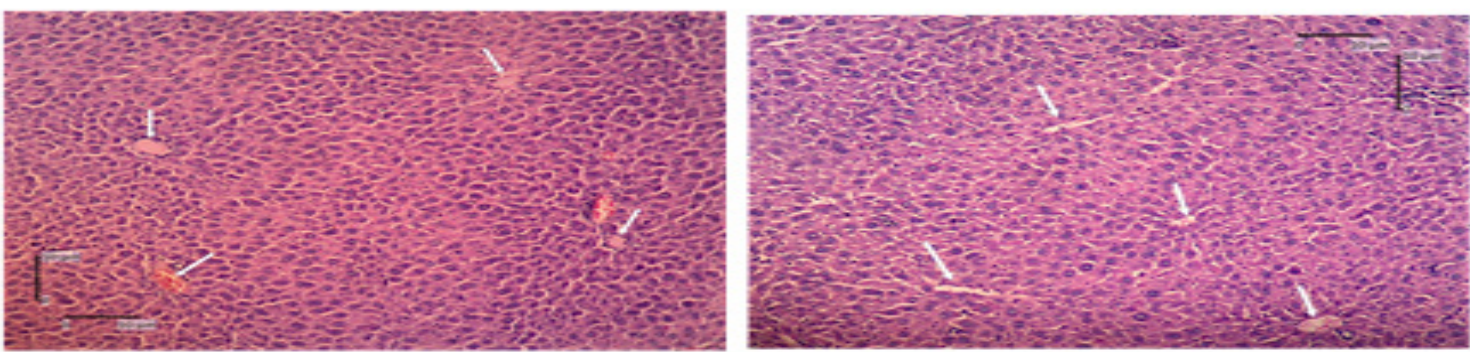

C

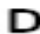

Gambar 1 Mikrostruktur Jaringan Hati Pembesaran 100x

(A). Kelompok I dan (B). Kelompok IV gambaran radier lempeng hepatosit hilang dan tidak ditemukan area nekrosis. (C). Kelompok II dan (D). Kelompok III lempeng hepatosit masih memiliki pola radier dengan vena sentral masih utuh serta tidak ditemukan area nekrosis. 


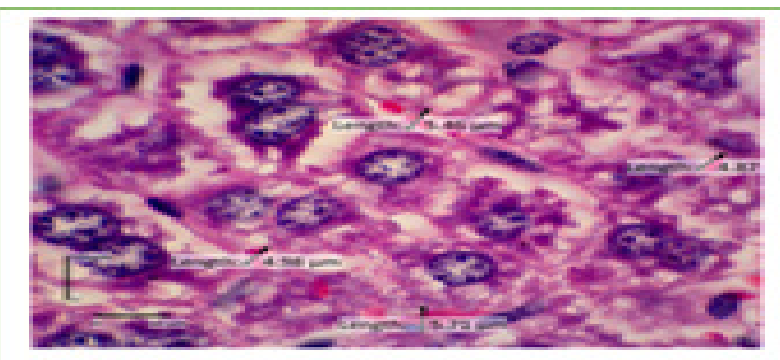

A

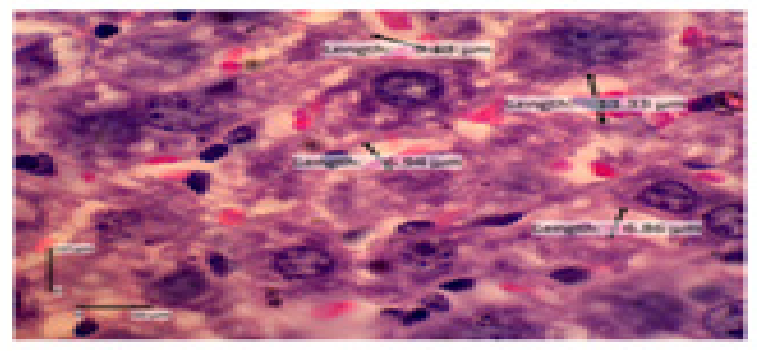

c

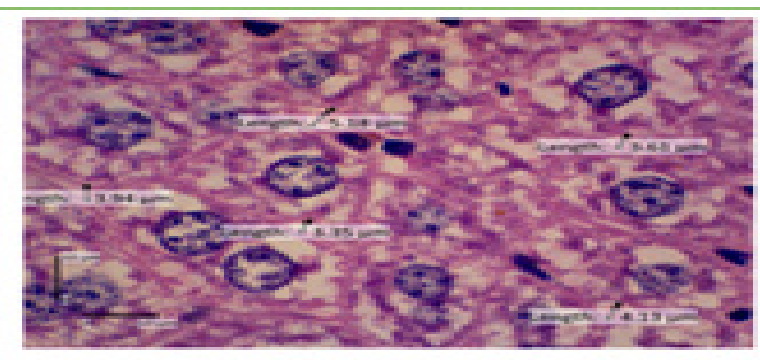

B

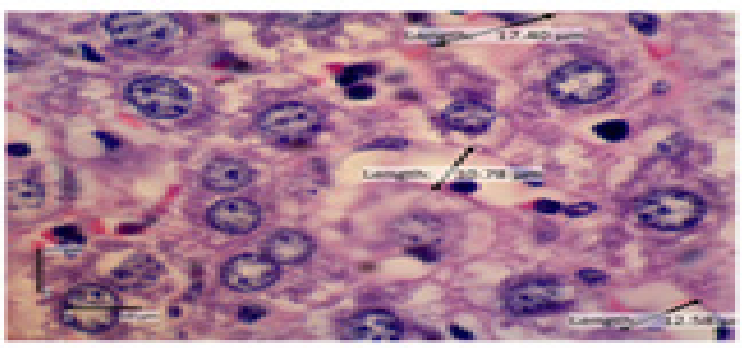

D

\section{Gambar 2 Mikrostruktur Jaringan Hati Pembesaran 1.ooox}

(A). Kelompok I dan (B). Kelompok IV h sel steatosis tampak jelas dengan lebar sinusoid tidak terlalu lebar. (C). Kelompok II dan (D). Kelompok III steatosis dengan jumlah lebih sedikit dengan diameter sinusoid yang melebar

Tabel 1 Rerata Jumlah Sel Steatosis dan Pelebaran Sinusoid Kelompok Kontrol dan Kelompok Perlakuan Fraksi Etil Asetat Jahe Gajah

\begin{tabular}{clcc}
\hline Variabel & \multicolumn{1}{c}{ Kelompok } & Rerata & Simpangan Baku \\
\hline \multirow{3}{*}{ Sel steatosis } & Kelompok I (kontrol) & 48,66 & 7,63 \\
& Kelompok II (perlakuan I) & 37,25 & 8,26 \\
& Kelompok III (perlakuan II) & 40,66 & 6,65 \\
& Kelompok IV (perlakuan III) & 38,00 & 8,71 \\
& Kelompok I (kontrol) & 5,54 & 0,89 \\
\multirow{2}{*}{ Lebar sinusoid } & Kelompok II (perlakuan I) & 4,37 & 0,55 \\
& Kelompok III (perlakuan II) & 6,02 & 1,30 \\
& Kelompok IV (perlakuan III) & 3,74 & 0,47 \\
\hline
\end{tabular}

dan jumlah pelebaran sinusoid pada setiap variabel kontrol dengan kelompok yang diberi fraksi etil asetat jahe gajah.

Tabel 1 menunjukkan rerata jumlah sel steatosis yang paling sedikit dimiliki oleh mencit kelompok perlakuan 1 (37,25). Rerata jumlah pelebaran sinusoid terkecil dimiliki oleh mencit kelompok perlakuan 3, yaitu 3,74. Kedua variabel tersebut menunjukkan hasil yang paling menjauhi rerata kelompok kontrol dan mempunyai simpang baku yang cukup kecil menunjukkan bahwa data tersebut dapat mewakili populasi yang besar.

Data di atas, analisis uji normalitas menggunakan Uji Saphiro Wilk didapatkan hampir seluruh nilai p >0,05, yaitu semua kelompok dari kedua variabel berdistribusi normal. Data yang berdistribusi normal bermakna dapat mewakili populasi kelompok sehingga dilakukan uji lanjutan, yaitu uji parametrik ANOVA satu arah.

Tabel 2 uji beda jumlah sel steatosis menunjukkan nilai $\mathrm{p}=0,139(>0,05)$ sehingga disimpulkan bahwa terdapat perbedaan jumlah sel steatosis antarkelompok tidak bermakna karena tidak bermakna maka tidak dilanjutkan dengan uji post-hoc. Selain itu, untuk uji beda pada pelebaran sinusoid menunjukkan nilai $\mathrm{p}=0,017(\mathrm{p}<0,05)$, artinya perbedaan jumlah pelebaran sinusoid antarkelompok bermakna sehingga dilakukan uji post-hoc menggunakan metode Tukey yang terlihat pada Tabel 3 . 
Tabel 2 Uji Beda Jumlah Sel Steatosis dan Pelebaran Sinusoid Kelompok Kontrol dengan Kelompok Perlakuan Fraksi Etil Asetat Jahe Gajah

\begin{tabular}{clcc}
\hline Variabel & \multicolumn{1}{c}{ Kelompok } & Rerata (Simpangan Baku) & Nilai p $^{*}$ \\
\hline \multirow{4}{*}{ Sel steatosis } & Kelompok I (kontrol) & $48,66(7,63)$ & 0,139 \\
& Kelompok II (perlakuan I) & $37,25(8,26)$ & \\
& Kelompok III (perlakuan II) & $40,66(6,65)$ & \\
& Kelompok IV (perlakuan III) & $38,00(8,71)$ & 0,017 \\
& Kelompok I (kontrol) & $5,54(0,89)$ & \\
Lebar sinusoid & Kelompok II (perlakuan I) & $4,37(0,55)$ & \\
& Kelompok III (perlakuan II) & $6,02(1,30)$ & \\
& Kelompok IV(perlakuan III) & $3,74(0,47)$ & \\
\hline
\end{tabular}

*) ANOVA (Analisis of varians)

\begin{tabular}{lc} 
Tabel 3 & $\begin{array}{l}\text { Pengaruh Dosis Pemberian Fraksi } \\
\text { Jahe Gajah terhadap Pelebaran } \\
\text { Sinusoid Dibanding dengan } \\
\text { Kelompok Kontrol }\end{array}$ \\
\hline \multicolumn{1}{c}{ Kelompok } & Nilai p p $^{*}$ \\
\hline Kontrol & 1,000 \\
Perlakuan I (0,78 mg/20 gBB/hari) & 0,070 \\
Perlakuan II (1,56 mg/20 gBB/hari) & 0,089 \\
Perlakuan III (3,12 mg/20 gBB/hari) & 0,052 \\
\hline Tukey Method &
\end{tabular}

Berdasar atas Tabel 3 uji statistik post hoc test (Tukey Method) pada derajat kepercayaan 95\% menunjukkan bahwa tidak ada perbedaan signifikan 3 (tiga) kelompok dosis dibanding dengan kelompok kontrol. Hasil kelompok fraksi jahe dengan dosis 3,12 $\mathrm{mg} / \mathrm{gBB}$ memberikan perbedaan terbesar dibanding dengan kontrol. Di antara ketiga dosis tersebut, fraksi jahe dosis $3,12 \mathrm{mg} / \mathrm{gBB}$ dapat memperbaiki pelebaran sinuoid.

Di bawah ini menunjukkan hasil uji korelasi untuk melihat seberapa kuat hubungan konsentrasi fraksi etil asetat jahe gajah dalam memengaruhi jumlah sel steatosis dan pelebaran sinusoid.

Tabel 4 Korelasi Konsentrasi Fraksi Jahe Gajah dengan Jumlah Sel Steatosis dan Pelebaran Sinusoid

\begin{tabular}{lcc}
\hline Korelasi Konsentrasi Fraksi & r & Nilai p*) \\
\hline dengan jumlah steatosis & $-0,451$ & 0,080 \\
dengan jumlah pelebaran sinusoid & $-0,381$ & 0,146 \\
\hline${ }^{*}$ Pearson Correlation Test & &
\end{tabular}

Tabel 4 menunjukkan bahwa nilai r negatif, artinya semakin besar pemberian konsentrasi fraksi etil asetat jahe gajah maka semakin sedikit jumlah sel steatosis dan semakin kecil pelebaran sinusoid. Berdasar atas kriteria Guilford (1956) hubungan konsentrasi dengan jumlah steatosis cukup berarti $\mathrm{r}=-0,451(>0,40-0,70)$, sedangkan korelasi antara konsentrasi dan pelebaran sinusoid memiliki hubungan yang rendah, tetapi pasti $\mathrm{r}=-0,381(>0,20-0,40)$, tetapi kedua variabel ini tidak bermakna secara statistik $(\mathrm{p}>0,05)$.

\section{Pembahasan}

Non-alcoholic fatty liver disease (NAFLD) merupakan penyakit perlemakan hati yang terjadi pada penderita sindrom metabolik. ${ }^{1}$ Pada sindrom metabolik terjadi peningkatan kadar stres oksidatif sehingga muncul sel steatosis dan tampak pelebaran sinusoid hati. Kerusakan pada jaringan hati dapat dilihat perubahan morfologi jaringan hati seperti hilangnya struktur portal pada arsitektur lobulus hati, pembengkakan sel hepatosit, perubahan susunan radier lempeng sel hepatosit, perubahan struktur sinusoid, degenerasi hidrofik, steatosis, dan nekrosis yang bersifat masif. Cara untuk mengetahui ada atau tidaknya kerusakan arsitektur lobulus hati, perubahan susunan radier lempeng sel hepatosit, dan nekrosis dapat diidentifikasi dengan melihat gambaran central vein yang utuh tanpa area nekrosis di sekitarnya. ${ }^{9}$

Pada penelitian ini mencit diberi sediaan fraksi etil asetat jahe gajah selama 28 hari. Jahe gajah merupakan obat herbal yang mengandung senyawa flavonoid. Senyawa flavonoid tersebut di dalam jahe gajah memiliki efek antioksidan (efek hepatoprotektif) dan antiinflamasi dengan cara menghambat xanthine oxidase yang bertanggung jawab dalam pembentukan ROS. Penghambatan ROS ini dapat mengurangi cedera sel hati yang ditandai dengan pelebaran sinusoid, nekrosis, dan steatosis pada penderita NAFLD. ${ }^{6,7}$

Observasi pada kelompok kontrol menunjukkan bahwa gambaran jaringan hati mulai kehilangan susunan radier lempeng sel hepatosit, central vein yang tampak utuh, dan tidak ada area nekrosis. Di samping itu, ditemukan sel hepatosit yang mengalami pembengkakan, sel hepatosit dengan droplet lemak (steatosis), dan pelebaran sinusoid hati. Kekacauan susunan lempeng sel hepatosit dapat terjadi akibat pembengkakan sel itu. Setelah pemberian fraksi etil asetat jahe gajah menunjukkan perbaikan kerusakan mikrostruktur jaringan hati pada kelompok II dan III dengan gambaran lempeng hepatosit yang radier mengelilingi vena sentral yang masih utuh dan tidak ditemukan area nekrosis. Selain itu, ditemukan sel steatosis dengan sinusoid yang melebar. Berbeda halnya dengan kelompok IV yang diberi konsentrasi fraksi jahe gajah paling tinggi menunjukkan hasil yang mendekati kelompok kontrol. Hal ini menunjukkan bahwa pemberian konsentrasi yang terlalu tinggi 
dapat menyebabkan drug induced liver injury (DILI) sehingga tidak boleh diberikan dalam konsentrasi yang terlalu besar.

Drug induced liver injury yang diawali dengan bioaktivitas obat akan menjadi metabolit reaktif yang mampu berinteraksi dengan makromolekul seluler seperti protein, lemak, dan asam nukleat. Hal ini menyebabkan disfungsi protein, peroksidasi lipid, kerusakan DNA, dan stres oksidatif sehingga dapat mencetuskan gangguan pada gradien ionik serta penyimpanan kalsium intraseluler yang menyebabkan disfungsi mitokondria dan juga gangguan produksi energi. Fungsi mitokondria yang hilang dan deplesi ATP menyebabkan pembengkakan dan lisis sel yang merangsang proses inflamasi lokal. ${ }^{10}$

Dilihat dari rerata jumlah sel steatosis hasil terbesar pada kelompok II, yaitu dengan rerata 37,250. Jumlah steatosis ini meningkat jumlahnya pada kelompok III dan menurun pada kelompok IV. Gambaran tersebut membentuk pola seperti kurva. Meskipun demikian, dilihat dari rerata jumlah sel steatosis kelompok perlakuan lebih sedikit dibanding dengan kontrol. Hal tersebut menunjukkan bahwa pemberian fraksi jahe gajah dapat memengaruhi jumlah steatosit jaringan hati pada mencit model sindrom metabolik meskipun secara statistik hasilnya tidak terdapat perbedaan yang bermakna.

Hasil uji-t pada rerata jumlah sel steatosis antara kelompok kontrol dan kelompok yang diberi terapi tidak terdapat perbedaan signifikan. Akan tetapi, dilihat dari nilai yang paling mendekati $(\mathrm{p}<0.05)$ adalah kelompok kontrol dengan perlakuan I. Hal ini berarti kelompok perlakuan I mempunyai jumlah sel steatosis yang lebih sedikit dibanding dengan kelompok perlakuan II dan III. Selanjutnya, dilakukan tes korelasi konsentrasi fraksi jahe gajah dengan jumlah sinusoid. Hasilnya menunjukkan nilai $\mathrm{r}$ negatif $(-0,451)$, artinya semakin besar pemberian konsentrasi fraksi etil asetat jahe gajah maka semakin sedikit jumlah sel steatosis. Berdasar atas kriteria Guilford (1956) hubungannya cukup berarti $(>0,40-0,70)$, tetapi hal ini tidak bermakna secara statistik $(\mathrm{p}>0,05)$.

Berdasar atas Tabel 2 tidak terdapat pengaruh yang bermakna pemberian fraksi etil asetat jahe gajah terhadap jumlah sel steatosis. Berbeda dengan penelitian lainnya yang menunjukkan hasil bermakna. ${ }^{11}$ Waktu pemberian terapi yang hanya 28 hari diduga mengakibatkan efek jahe gajah itu kurang sehingga diperlukan waktu yang lebih lama untuk melihat pengaruh yang lebih efektif. Penetuan lama waktu penelitian mengikuti penelitian sebelumnya oleh Yulianti dkk. ${ }^{8}$ yang memberikan hasil yang sama, yaitu belum bermakna secara signifikan. Pengaruh lainnya adalah waktu pemberian fraksi etil asetat jahe gajah yang tidak menetap setiap harinya yang memengaruhi onset of action sehingga efek yang diberikan akan berbeda. Selain itu, terdapat juga faktor lain seperti subjek yang kurang karena jika semakin banyak data yang didapatkan akan semakin bagus hasil statistik karena banyak data yang bervariasi.

Hasil uji statistik ANOVA rerata jumlah pelebaran sinusoid jaringan hati pada kelompok yang diberi terapi fraksi jahe gajah memperlihatkan hasil yang bermakna. Bila dilihat dari rerata tiap-tiap kelompok pelebaran sinusoid yang paling rendah terdapat pada kelompok IV, hal ini tentu berbanding terbalik dengan jumlah sel steatosis yang banyak pada kelompok ini. Keadaan ini disebabkan oleh sel steatosis yang terlalu banyak disertai sel yang bengkak dengan sitoplasma yang melebar ke arah sinusoid mengakibatkan lebar sinusoid tampak mengecil. Selanjutnya, dilaksanakan uji beda menggunakan Metode Tukey tidak terdapat perbedaan signifikan. Akan tetapi, dilihat dari nilai yang paling mendekati $(\mathrm{p}<0,05)$ adalah kelompok kontrol dengan perlakuan III (kelompok IV), artinya kelompok perlakuan III mempunyai jumlah pelebaran sinusoid yang lebih kecil dibanding dengan kelompok perlakuan I dan II. Kemudian, dilanjutkan dengan uji korelasi menggunakan Pearson Correlation Test menunjukkan nilai $\mathrm{r}$ negatif $(-0,381)$, artinya semakin besar pemberian konsentrasi fraksi etil asetat jahe gajah maka pelebaran sinusoid tidak terlalu besar. Berdasar atas kriteria Guilford (1956) mempunyai hubungan hubungan yang rendah, tetapi pasti $(>0,20-$ $0,40)$, tetapi tidak bermakna secara statistik ( $>0,05)$.

Secara keseluruhan fraksi etil asetat jahe gajah dalam penelitian ini dapat memengaruhi mikrostruktur jaringan hati pada mencit model metabolik. Belum ada penelitian yang serupa, akan tetapi hasil ini juga sesuai dengan penelitian di Cina, India, Mesir, Amerika, Pakistan, dan Malaysia bahwa kandunganyang terdapat dalam jahe gajah menunjukkan efek hepatoprotektif oleh karena kandungan senyawa polifenol (6-gingerol, shogaols) di dalamnya mempunyai antioksidan yang tinggi. Gingerol memiliki efek penghambatan pada xanthine oxidase yang bertanggung jawab dalam pembentukan reactive oxygen species (ROS) seperti anion superoksida. Penghambatan ROS tersebut dapat mengurangi kejadian pelebaran sinusoid, nekrosis, dan steatosis jaringan hati pada penderita NAFLD. ${ }^{6,7}$

\section{Simpulan}

Dalam penelitian ini baik pengamatan histopatologi maupun analisis statistik telah membuktikan bahwa pemberian fraksi etil asetat jahe gajah memengaruhi mikrostruktur jaringan hati mencit model sindrom metabolik.

\section{Ucapan Terima kasih}

Ucapan terima kasih ditunjukan kepada Laboratorium Farmasi ITB, Laboratorium Biomedik Gedung Fakultas Kedokteran Unisba, Laboratorium Central Unpad lantai 3, dan Laboratorium Hewan Unpad.

\section{Daftar Pustaka}

1. Adiwinata R, Kristanto A, Christianty F, Richard T, Edbert D. Tatalaksana terkini perlemakan hati non alkoholik. JPDI. 2015;2(1):53-9.

2. Dyson JK, Anstee QM, McPherson S. Non-alcoholic fatty liver disease: a practical approach to treatment. Frontline Gastroenterol. 2014 Oct;5(4):277-86.

3. Halegoua-De Marzio DL, Fenkel JM. Concepts and treatmet approaches in nonalcoholic fatty liver 
disease: Advances Hepatol. 2014:1-7. (diunduh 20 Agustus 2018). Tersedia dari: https://www. hindawi.com/journals/ahe/2014/357965/.

4. Kumar V, Abbas AK, Fausto N, Aster J. Robbins \& Cotran pathologic basis of disease. Edisi ke-8. Philadelphia: Saunders; 2010.

5. Chalasani N, YoubossiZ, Lavine JE, Diehl AM, Brunt $\mathrm{EM}$, Cusi K, dkk. The diagnosis and managemen of non-alcoholic fatty liver disease: pactice guideline by the American Assosiation or the Study of Liver Disease, American Collage of Gastroenterology, and the American Gastroenterological Assosiation. Hepatology. 2012;55(6):2005-23.

6. Tzeng TF, Liou SS, Chang CJ, Liu IM. 6-gingerol protects against nutritional Steatohepatitis by regulating key genes related to inflammation and lipid metabolism. Nutrients. 2015;7(2):999-1020.

7. Author C, Sikkim E, Authors C. Pharmacognosy Zingiber officinale: a natural gold. Int J Pharma Bio
Sci. 2011;2(1):283-94.

8. Yulianti AB, Widayanti, Rahmawati I. Efek proteksi campuran ekstrak bawang putih, jahe gajah, dan lemon terhadap kadar kolesterol total darah pada mencit tua yang terpapar diet tinggi lemak. Prosiding SNaPP2017 Kesehatan. 2017;3(1):21521.

9. Motawi TK, Hamed MA, Shabana MH, Hashem $\mathrm{RM}$, Abdul AFN. Zingiber officinale acts as a nutraceutical agent against liver fibrosis. Nutr Metabolism (Lond). 2011;8:40. doi:10.1186/17437075-8-40.

10. Loho IM, Hasan I. Drug-induced liver injury tantangan dalam diagnosis. CDK. 2014;41(3):16770.

11. Al-Katib SM, Al-Khashab EM, Kalo MS, Hamdoon AA. The antioxidant effects of flavonoids and non flavonoid part extracted from Ginger (Zingiber officinale) roots. Jou Raf Sci. 2009;20(3):18-31. 